\title{
C \\ CONCENTRATIONS OF A WATER SOLUBLE, GAS-PHASE MERCURY SPECIES IN AMBIENT AIR: RESULTS FROM MEASUREMENTS AND MODELING
}

\author{
S. E. Lindberg \\ Environmental Sciences Division, Oak Ridge National Laboratory ${ }^{1}$, \\ PO Box 2008, Oak Ridge, TN 37831 \\ W. J. Stratton \\ Department of Chemistry, Earlham College, Richmond, IN \\ P. Pai \\ Atmospheric and Environmental Research, San Ramon, CA \\ M.A. Allan \\ Electric Power Research Institute, Palo Alto, CA
}

\begin{abstract}
There are few reliable data on the speciation of $\mathrm{Hg}$ in ambient air, although this information is critical to understanding the fate of $\mathrm{Hg}$ once released from point sources. The water soluble species of $\mathrm{Hg}$ that are thought to exist in flue gases would be subject to far greater local removal rates than is elemental $\mathrm{Hg}$ vapor, but methods are lacking to quantify this species. We developed a method using refluxing mist chambers to measure the airborne concentrations of reactive gaseous mercury (RGM) in short-term samples under ambient conditions. The method exhibits an effective detection limit of $0.02 \mathrm{ng} / \mathrm{m}^{3}$ and a precision for ambient concentration levels of \pm $20-30 \%$. Using a model that simulates atmospheric transport and fate of anthropogenic mercury emissions over the contiguous United States, we generated 24-hr RGM concentrations to compare to the measurement data. The average RGM concentrations measured with our mist chambers at sites in Tennessee (TN) and Indiana (IN) were $0.065 \mathrm{ng} / \mathrm{m}^{3}$ and $0.100 \mathrm{ng} / \mathrm{m}^{3}$, respectively. These averages represent about $3 \%$ of total gaseous mercury (TGM), and RGM generally exceeds regional particulate $\mathrm{Hg}$. The 24-hr model-simulated RGM concentration averages in the modeling grid cells representing TN and $\mathbb{N N}$ are $0.051 \mathrm{ng} / \mathrm{m}^{3}$ and $0.098 \mathrm{ng} / \mathrm{m}^{3}$ respectively, in good agreement with the data. The measured concentrations at the two sites exhibit weak positive correlations with temperature, solar radiation, $\mathrm{O}_{3}, \mathrm{SO}_{2}$, and TGM. These concentrations are high enough to suggest that RGM can play an important role in both wet and dry deposition on a regional scale.
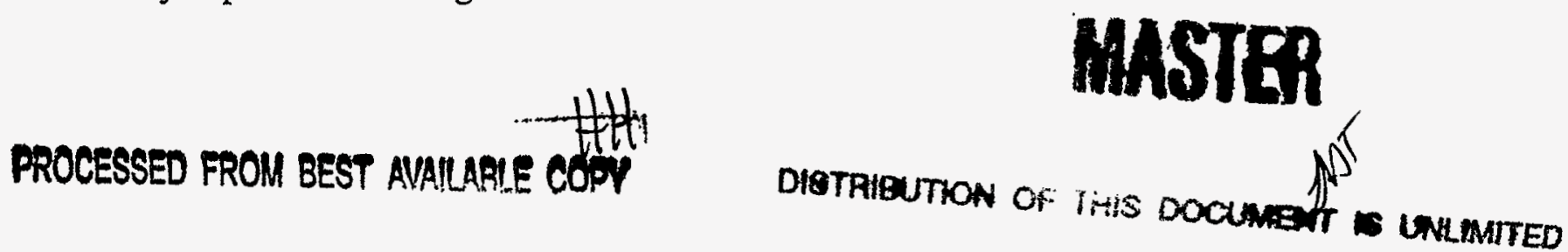

\footnotetext{
${ }^{1}$ Research sponsored by the Electric Power Research Institute under contract with ORNL. ORNL is a managedby Lockheed-Martin Energy Research, Inc. for the U.S. Department of Energy.
} 


\section{DISCLAMMER}

This report was prepared as an account of work sponsored by an agency of the United States Government. Neither the United States Government nor any agency thereof, nor any of their employees, makes any warranty, express or implied, or assumes any legal liability or responsibility for the accuracy, completeness, or usefulness of any information, apparatus, product, or process disclosed, or represents that its use would not infringe privately owned rights. Reference herein to any specific commercial product, process, or service by trade name, trademark, manufacturer, or otherwise does not necessarily constitute or imply its endorsement, recommendation, or favoring by the United States Government or any agency thereof. The views and opinions of authors expressed herein do not necessarily state or reflect those of the United States Government or any agency thereof. 


\section{DISCLAIMER}

Portions of this document may be illegible in electronic image products. Images are produced from the best available original document. 


\section{Measurement Methods}

The high-flow refluxing mist chamber (Figure 1) consists of a glass base and a Teflon top. Ambient air at 15-20 SLPM is pulled in through the bottom and mixes with a fine mist of a suitable scrubbing solution to remove water-soluble gases ${ }^{8,12}$. A hydrophobic membrane at the outlet retains the micron-sized liquid droplets so that the liquid refluxes continuously. In this fashion, a small volume of solution (ca. $0.02 \mathrm{~L}$ ) can scrub ca. $1000 \mathrm{~L}$ of air in a one-hour sampling period. For efficient retention of RGM (i.e. $\mathrm{Hg}$ (II) species), the essential characteristic of the scrubbing solution is a relatively high concentration of $\mathrm{Cl}$ ion, (either as $\mathrm{HCl}$ or an $\mathrm{NaCl} / \mathrm{HCl}$ mixture) to facilitate formation of the $\mathrm{HgCl}$ - ion which has a high water solubility. Studies reported here used either $0.05 \mathrm{M} \mathrm{HCl}$ or $0.25 \mathrm{M} \mathrm{NaCl} / 0.05 \mathrm{M} \mathrm{HCl}$. Samples were collected in glass or plastic vials for transport to a laboratory, where they were analyzed (usually within 6 hours) for reactive $\mathrm{Hg}$ by stannous chloride reduction and cold vapor atomic flourescence with dual gold trap amalgamation ${ }^{13}$. We have recently developed an approach for rapid in-field analysis of $\mathrm{MC}$ samples using a Tekran $\mathrm{Hg}$ analyzer. With this method we can quantify RGM in ambient air within a few minutes. The method detection limit (3x std. dev. of mist chamber blanks) is estimated to be $20 \mathrm{pg}$ which corresponds to $0.02 \mathrm{ng} / \mathrm{m}^{3}$ for 1 -hour samples; lower for longer sampling times. Figure 2 shows a representative set of data for sideby-side measurement of RGM using two matched mist chambers. There is a significant amount of scatter at the low levels of RGM found in ambient air and this pair of mist chambers showed a modest bias on the order of $20 \%$.

Two possible sources of artifact RGM have been investigated in our lab: (a) formation of RGM within the mist chamber by reaction of $\mathrm{Hg}(0)$ with ozone or other photochemically-induced oxidants and (b) co-sampling of particulate $\mathrm{Hg}$. Challenge tests with elevated $\mathrm{Hg}(0)$ and ozone indicate negligible $(<5 \%)$ artifact formation under normal ambient conditions for short ( $c a .1$ hour) samples. Likewise, co-sampling of particulate $\mathrm{Hg}$ was found to be negligible at our rural sites.

\section{Measurement Sites}

From 1992 - 1995 we sampled RGM and TGM at two field sites: $~ 30 \%$ of the data were collected at Walker Branch Watershed (WBW) in east-central Tennessee, during the summers of 1992,1993 , and 1995. WBW is an upland forest at $\sim 330 \mathrm{~m}$ elevation, located approximately 20 $\mathrm{km}$ from two large $(\sim \mathrm{GW})$ coal-fired power plants which are often upwind of the site (SW and $\mathrm{NE}$ ). Most samples were collected $-2 \mathrm{~m}$ above the ground in a forest clearing of $1.5 \mathrm{ha}$. Related atmospheric chemistry and meterological data were collected by NOAA ${ }^{14}$. About $70 \%$ of our data were collected on the Earlham College (EC) campus in Richmond, Indiana during spring and summer 1993, 1994, and 1995. Richmond is a small city at the Ohio/Indiana border, $\sim 60$ $120 \mathrm{~km}$ from the nearest large cities and numerous major coal-fired power plants located along the Ohio River Valley to the south and west (generally upwind) of the site. Most sampling was done over open grass and paved surfaces, approximately $1.5 \mathrm{~m}$ above the ground, but $\sim 25 \%$ of the samples were collected on the roof of a $12-\mathrm{m}$ tall building. A $0.06 \mathrm{GW}$ coal-fired power plant is located $\sim 3 \mathrm{~km}$ generally downwind of the site. 
monitors indicated a sharp spike in $\mathrm{SO}_{2}$ following late-morning breakup of the local inversion layer. The WBW site is often impacted by plume fumigation events from one of three local power plants (two coal plants of 0.9 and $1.2 \mathrm{GW}$, located $\sim 15-20 \mathrm{~km} \mathrm{NE}$ and $S W$, respectively, and a small, variable-fuel steam boiler to the $\mathrm{N}$, not operating in summer and therefore not relevant to this study), and such spikes in $\mathrm{SO}_{2}$ are common ${ }^{15}$. Upon later analysis, our data revealed a similar spike in $\mathrm{RGM}$ which coincided with the behavior of $\mathrm{SO}_{2}$ (Figure 5). During this period, the RGM/TGM ratio increased three-fold, then dropped to more typical levels as both $\mathrm{SO}_{2}$ and $\mathrm{RGM}$ decreased. Winds measured aloft on our nearby $44-\mathrm{m}$ tower indicated that transport during this period was from the $S W$, site of the $1.2 \mathrm{GW}$ power plant. These observations are not direct evidence of a source/receptor relationship, but the data clearly point to the need for source-related studies of RGM in both plume and ambient air, such as those published for $\mathrm{TGM}^{16}$.

\section{Regional Modeling of the Behavior of RGM in Ambient Air}

\section{Approach}

The long-range transport and fate of atmospheric mercury was simulated using the Trace Elements Analysis Model (TEAM), the details of which are described elsewhere ${ }^{17}$. Here we briefly describe the model features that are relevant to the simulation results described in the next section.

The regional transport, chemistry, and deposition of a three-species mercury system (gaseous elemental mercury, gaseous divalent mercury or RGM, and particulate mercury) was modeled using an Eulerian, i.e., fixed, three-dimensional grid system with regular spacing in the horizontal and non-uniform spacing in the vertical. The horizontal spacing is $100 \mathrm{~km}$ on a map that projects locations on the spherical earth onto a horizontal plane; the method used to perform this transformation is referred to as polar stereographic projection. The horizontal grid system has 63 by 47 grid cells and is shown in Figure 6.

The three-dimensional grid system of TEAM uses 6 levels in the vertical, with spacing that varies from $60 \mathrm{~m}$ close to the surface to $1500 \mathrm{~m}$ at the highest level. In each three-dimensional grid box the partial differential equation (pde) describing the mass conservation equation for the three mercury species is solved. The pde represents mass balance of each mercury species in the grid box and accounts for the following processes: emissions of the species in the box, inflow and outflow of mass into the box through transport of winds, the formation and destruction of species in the box through chemical transformation, and removal of mass by wet and dry deposition. Before the pde's can be solved they are transformed into a set of coupled algebraic equations in which the unknowns are the concentrations of the three mercury species in each grid box of $100 \mathrm{~km} \times 100 \mathrm{~km}$ in the horizontal. The removal of mass by wet and dry deposition is also kept track of by TEAM for each of the grid boxes in the lowest, i.e., surface, model layer. Thus the output from the model consists of estimates of concentrations (in mass/volume), wet deposition flux (in mass/area), and dry deposition flux (in mass/area) for the following three mercury species: gaseous elemental mercury, i.e., $\mathrm{Hg}^{\circ}$, reactive gaseous mercury, i.e., $\mathrm{Hg}$ (II) or RGM, and particulate mercury, i.e., $\mathrm{Hg}(\mathrm{p})$. The model estimates are saved as model output for 


\section{Results from Model Simulations}

In a previous study the base case simulation results of TEAM were compared against concentrations and deposition measurements published for several locations in the states of MI, $\mathrm{MN}, \mathrm{WI}, \mathrm{TN}, \mathrm{FL}, \mathrm{NY}$, and $\mathrm{VT}^{17}$. These comparisons showed that the model captured the range of observed values for both concentrations and deposition of total $\mathrm{Hg}$ in most states. Moreover, the model estimates also reproduced the observed spatial gradients in mercury wet deposition amounts and ambient concentrations. For each of the 7 states, the range of model estimates in the surface layer grid cells comprising a state was compared to the range of surface measurements in one or several locations in that state. The rationale for comparing the ranges in model estimates and measurements rather than comparing point measurements in a given year with grid-cell average estimates in a different year has been discussed elsewhere ${ }^{17}$. We will use the same evaluation technique in this study and compare the RGM and TGM measurements at Walker Branch Watershed (WBW) and Earlham College (EC) against 24-hour average concentrations estimated by the model in the grid cells comprising the states of TN and $\mathbb{I N}$, respectively. There are approximately 20 grid cells comprising each of the two states as shown in Figure 6.

A frequency distribution of the 24-hour average concentrations of RGM and RGM/TGM ratio in the grid cells of TN and IN for each day of the year 1990 is shown in Figure 7a. Also shown is the corresponding distribution of all the grid cells of the modeling "domain" (the domain includes all 2961 cells shown in Fig. 6). Overall the 24-hr concentration of RGM in the domain averaged to $0.025 \mathrm{ng} / \mathrm{m}^{3}$, while the $24-\mathrm{hr}$ concentrations in TN and IN averaged to $0.05 \mathrm{ng} / \mathrm{m}^{3}$ and $0.098 \mathrm{ng} / \mathrm{m}^{3}$. These are comparable to the average of $0.065 \mathrm{ng} / \mathrm{m}^{3}$ measured at WBW in TN and of $0.10 \mathrm{ng} / \mathrm{m}^{3}$ measured at EC in IN (Table 1). However, it should be noted that over $90 \%$ of the data summarized in Table 1 represent daytime measurements, and not 24-hr means. As shown in Figure 7(a), most 24-hr RGM concentrations in the TN grid cells ranged from 0.04 to $0.1 \mathrm{ng} / \mathrm{m}^{3}$ while a significant fraction of the IN grid cells experienced RGM concentrations over $0.1 \mathrm{ng} / \mathrm{m}^{3}$. The frequency distribution of modeled RGM concentrations in TN and IN compares quite well with the frequency distribution of measured RGM concentrations at Walker Branch Watershed, TN and Earlham College, IN (Fig. 8).

The 24-hr TGM concentrations averaged $1.6 \mathrm{ng} / \mathrm{m}^{3}, 1.7 \mathrm{ng} / \mathrm{m}^{3}$ and $1.8 \mathrm{ng} / \mathrm{m}^{3}$ for the grid cells in the domain, TN, and IN, respectively. Most RGM concentrations in the domain represent only 1$2 \%$ of the TGM concentrations which are dominated by a model input background concentration of $1.6 \mathrm{ng} / \mathrm{m}^{3}$. However, the RGM concentrations in TN represent $2-5 \%$ of TGM which is consistent with the measurements at WBW. A comparison of frequency distributions of modeled RGM/TGM ratio shown in Figure $7 \mathrm{~b}$ against measurements indicates that the model estimated ratio in TN and $\mathrm{IN}$ compares well with the measurements in these states (e.g., see Fig. 16 in Ref. 10). An examination of Figure $7 \mathrm{~b}$ shows that model estimates of RGM represent a range of 5-9\% of TGM in a significant number grid cells in IN whereas measurements at EC indicate a generally lower fraction of data in that range (Table 1). The reason for this is not clear at this time but it is interesting to note in Table 1 that the measurements at Earlham College show a much stronger seasonal trend in mercury concentrations as compared to the measurements at WBW. If these seasonal trends in concentrations are related to emissions and/or chemistry, we 

Iverfeldt, M. Meili, and B. Tim. "Mercury in the Swedish environment-Recent Research on Causes, Consequences and Corrective Methods," Water Air Soil Pollut.," Vol. 55, pp. 1-261. Exchange of Mercury in a Forest: Results of Modeling and Gradient Approaches," J. Geophys. Res., Vol. 97, pp. 2519-2528.

Expert Panel on Mercury Atmospheric Processes, "Mercury Atmospheric Processes: A Synthesis Report," Workshop Proceedings, EPRI/TR-104214, Tampa, Florida (September 1994).

P. Pai, P. Karamchandani, and C. Seigneur. "Simulation of the regional atmospheric transport and fate of mercury using a comprehensive mercury model", Atmos. Environ., Vol. 31, pp. 2717-2732 (1997).

C. Seigneur, J. Wrobel, and E. Constantinous, "A Chemical Kinetic Mechanism for Atmospheric Inorganic Mercury," Envir. Sci. Technol., Vol. 28 p. 1589.

G. Petersen, J. Munthe, and R. Bloxam, Global and Regional Mercury Cycles: Sources, Fluxes and Mass Balances, 1995, pp. 191-217.

W. R. Cofer, V. G. Collins, and R. W. Talbot, "Improved Aqueous Scrubber for Collection of Soluble Atmospheric Trace Gases," Environ. Sci. Technol., Vol. 19, pp. 557-560.

W. J. Stratton and S. E. Lindberg, "Use of a Refluxing Mist Chamber for Measurement of Gas-Phase Mercury (II) Species in the Atmosphere," Water, Air, Soil, Pollut., Vol. 80, pp. 1269-1278.

S. E. Lindberg and W. J. Stratton, "Atmospheric Mercury II Speciation: Concentrations and Behavior of Reactive Gaseous Mercury in Ambient Air, Envir. Sci. Technol., in press.

W. J. Stratton and S. E. Lindberg, "Atmospheric Hg Speciation: Testing and Evaluation of a Refluxing Mist Chamber for Measurement of Reactive Gaseous Hg in Ambient Air," (in review).

W. C. Keene, J. R. Maben, A. A. P. Pszenny, and J. N. Galloway, "Measurement Technique for Inorganic Chlorine Gases in the Marine Boundary-Layer," Envir. Sci. Tech., Vol. 27, pp. 866-874. Low-Temperature Gas Chromatography with Cold-Vapor Atomic Fluorescence Detection," Anal. Chim. Acta, Vol. 208, p. 151.

B. B. Hicks, R. P. Hosker, Jr., T. P. Meyers and J. D. Womack, "Dry Deposition Inferential Measurement Techniques-I. Design and Tests of a Prototype Meteorological and Chemical System for Determining Dry Deposition" Atmos. Envir., Vol. 25A, pp. 2345-2359.

D. R. Matt, R. T. McMillen, J. D. Womack, and B. B. Hicks, "A Comparison of Estimated and Measured $\mathrm{SO}_{2}$ Deposition Velocities," Water, Air, and Soil Pollut., Vol. 36, pp. 331-347.

S. E. Lindberg, "Mercury Partitioning in a Power Plant Plume and Its Influence on Atmospheric Removal Mechanisms," Atmos. Environ., Vol. 14, pp. 227-231.

P. Pai, P. Karamchandani, and c. Seigneur. "Simulation of the regional atmospheric transport and fate of mercury using a comprehensive mercury model", Atmos. Environ., Vol. 31, pp. 2717-2732 (1997). 


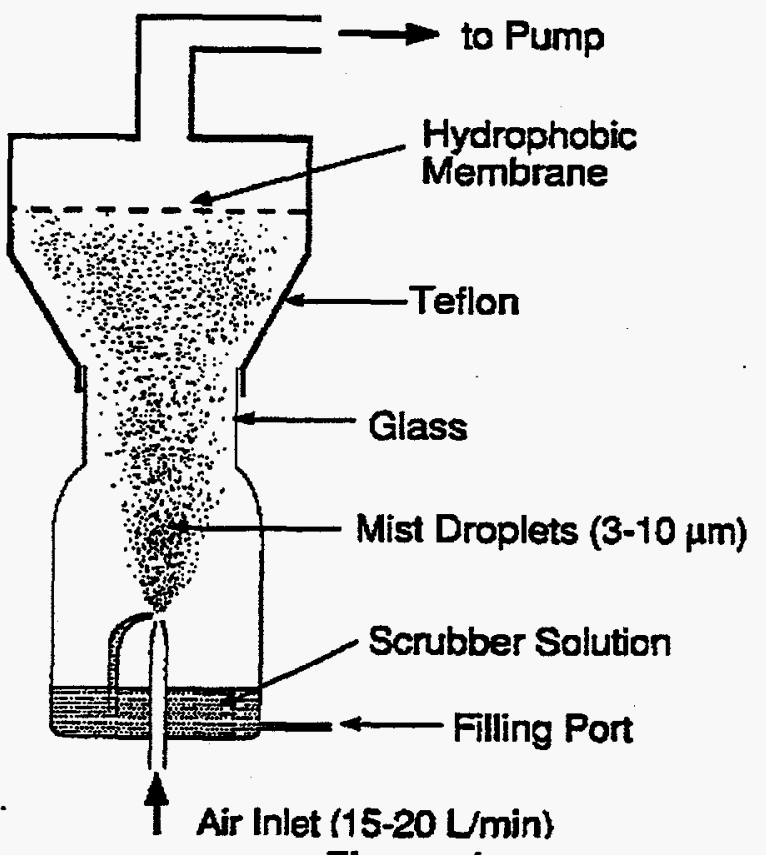

Figure 1

Schematic of the refluxing mist chamber used to collect RGM

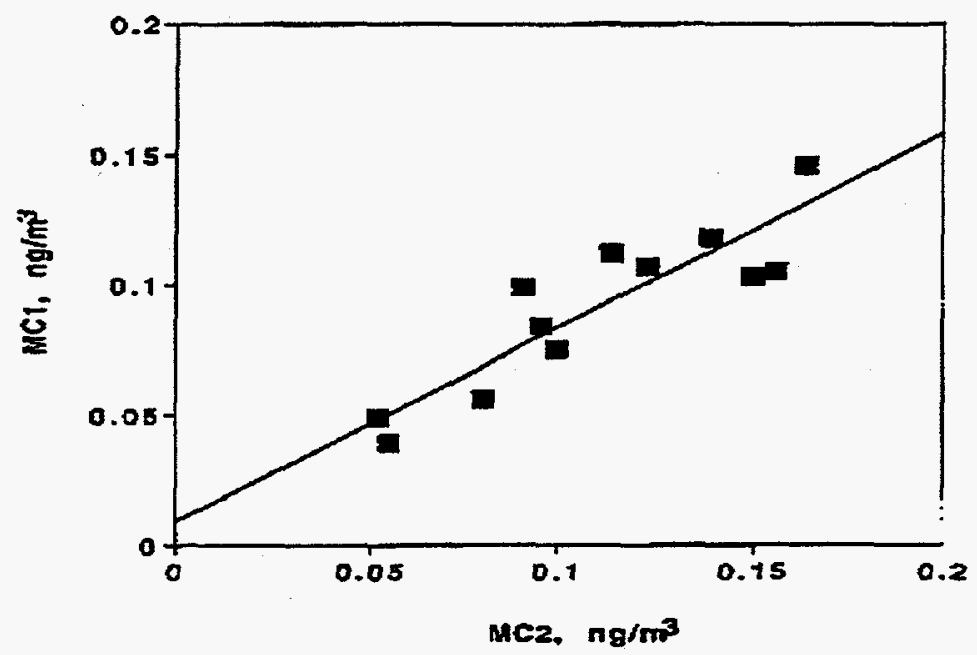

Figure 2

Comparison of results for RGM measurements in adjacent mist chambers 


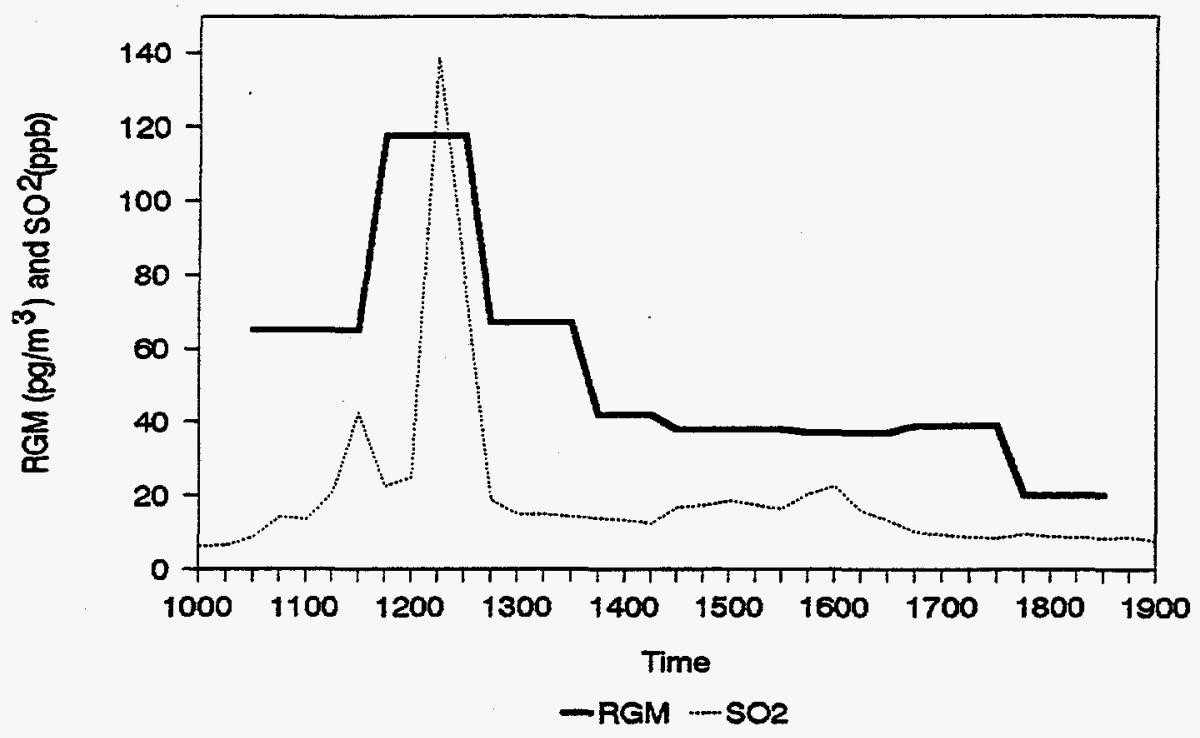

Figure 5

Temporal trends in $\mathrm{SO}_{2}$ and $\mathrm{RGM}$ measured at WBW on August 3, 1993 (times are EST)

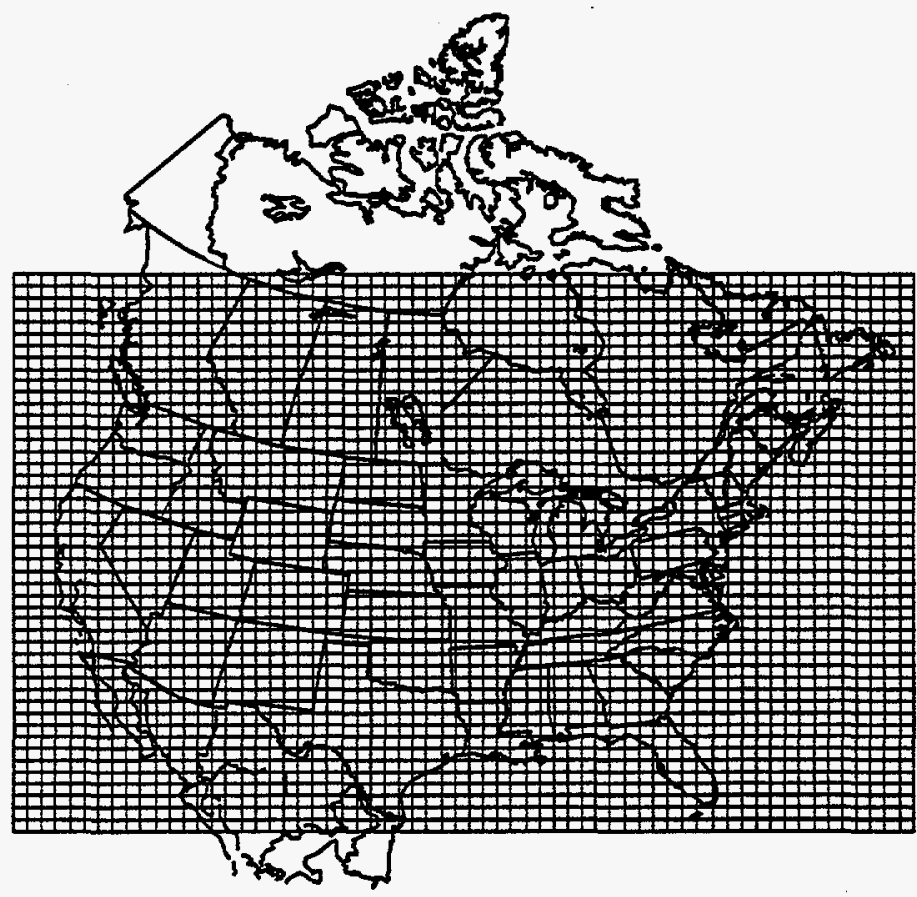

Domain and grid system for regional modeling of trace metals

Figure 6

The modeling domain 


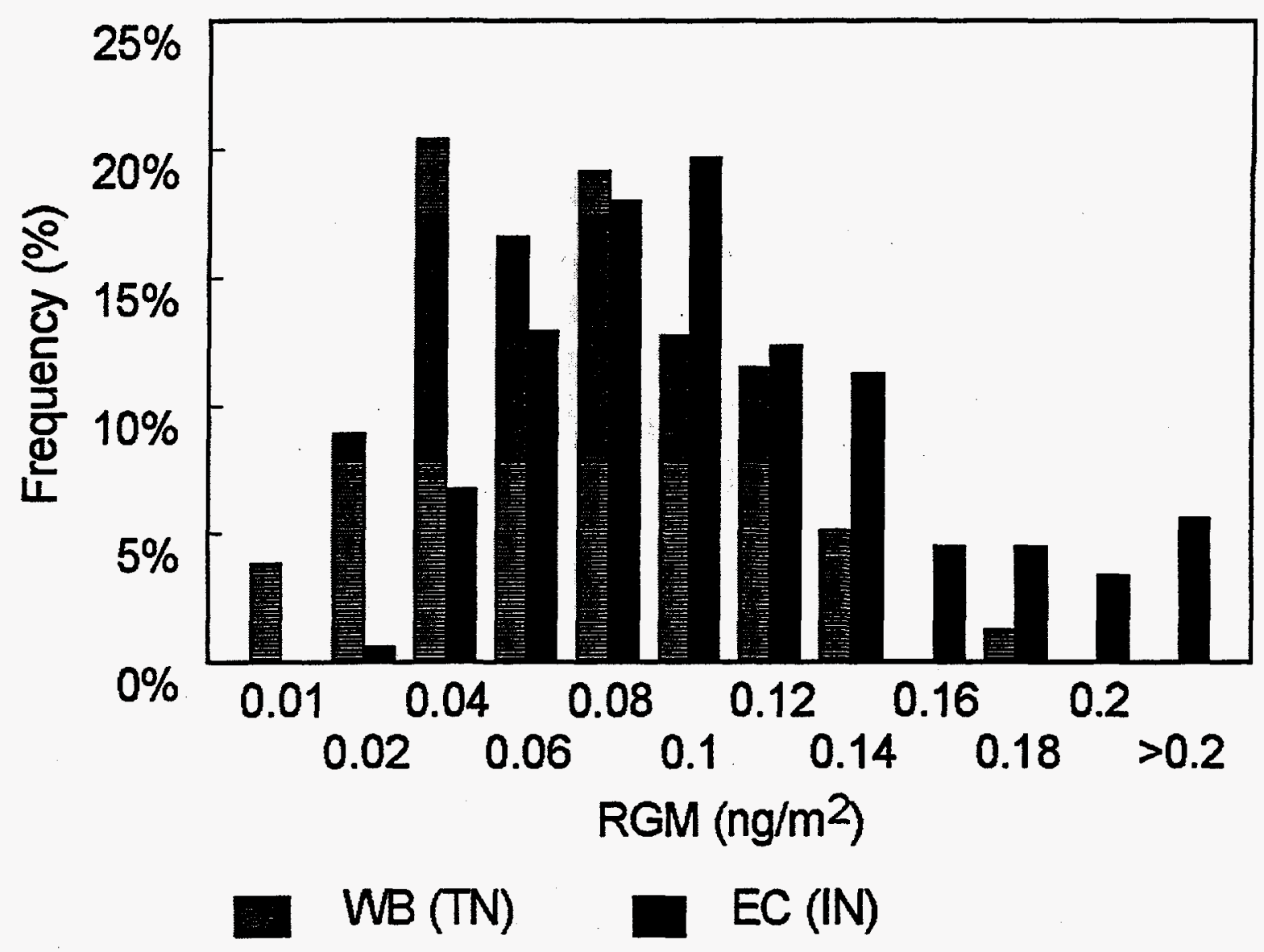

Figure 8 